Turkey's

\section{flower powers}

\section{PETER COLLINS REPORTS}

THE recent decision of the Turkish 1 government to make trade in opium poppy "straw" a state monopoly is a logical step in the process of assuming complete control of the production and marketing of this crop. It should also reassure those interested people outside Turkey who were surprised, if not distressed, at the announcement some months ago that the ban on growing the opium poppy (Papaver somniferum) had been rescinded. In fact, the lifting of the ban, although said originally to have been suggested for political reasons, was almost essential if widespread distress, possibly starvation, were not to be inflicted on the many thousands of farm families for whom this crop provides almost the sole source of income.

The story of this latest phase in poppy cultivation in Turkey goes back to the beginning of the $1970 \mathrm{~s}$. At that time, the United States government, acutely aware of the threat of heroin addiction among its younger population, came to regard Turkey as the main source of the opium from which that drug is derived. Thanks largely to the work of the United Nations Narcotics Laboratory in Geneva, it is possible to establish the provenance of opium samples with reasonable accuracy but in any event there is ample other evidence to support this view, although only a small proportion of the world's total opium is grown in Turkey. Determined to deal with the heroin problem, the United States persuaded the Turkish government to prohibit all cultivation of the opium poppy, an announcement made somewhat dramatically at a meeting of the United Nations Commission on Narcotic Drugs in Geneva in 1972. Moreover, it is certainly true that, following the ban, there was a rapid decline in the amount of heroin coming on the market, not only in the United States but also in the Riviera, where there was at one time said to be a "heroin famine".

The Turkish ban was imposed on the understanding that the United States would provide the funds-estimated at $\$ 35$ million-for recompensing the farmers who were being deprived of their main cash crop, and for the very large research and development programme required to find alternative

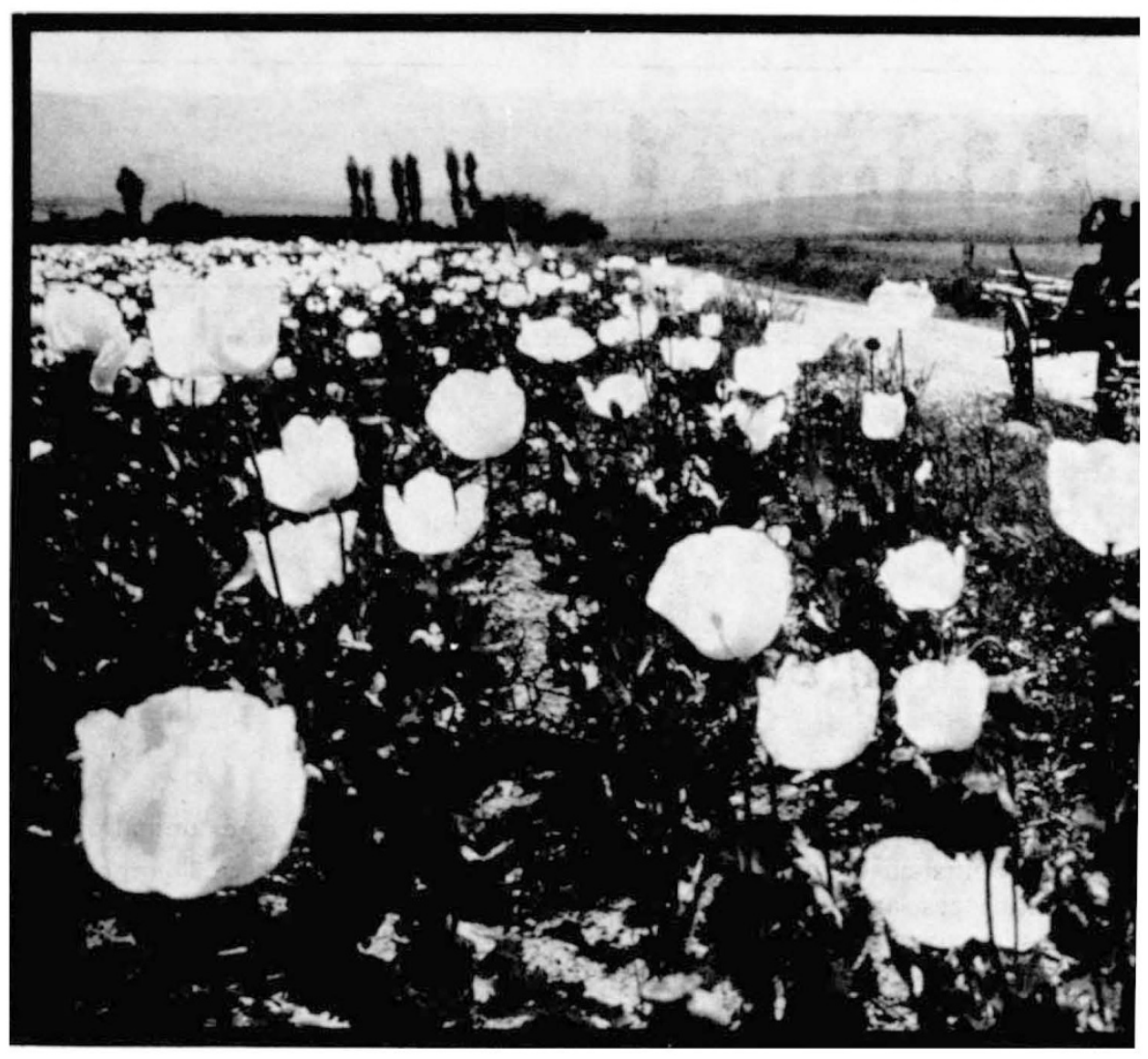

crops or other occupations. In the event, while several million dollars were handed out as compensation, the cropsubstitution programme never really got off the ground-a factor that may also have influenced the Turks in their change of mind.

The fact is that in those areas of Turkey where the poppy has traditionally been grown, almost no other cash crop will succeed. Poor soils, low rainfall, extremes of heat and cold make normal agriculture difficult, often impossible, over much of those provinces -Afyon, Burdur, Denizli, Isparta-in the south-western part of the Anatolian plateau. To the problems posed by soil and climate were added that natural resistance to change of any agricultural population, especially when that change was apparently being made to please a foreign power for whom in any event they had no particular affection. In fact. the difficulty of substituting new crops. and ideas amounting almost to a new wav of life. for opium poppy cultivation has been known ever since the late 1950s when the UN Food and Agriculture Organisation (FAO) became involved in this tvpe of operation in Iran; and the Americans. with their teams of willing but perhaps oversophisticated experts under AID, were even less successful than previous efforts in this direction. It seems almost as though AID was landed with a vast project which it would almost certainly have rejected had it been suggested to it in the ordinary way of technical assistance.

At this early stage, the United Nations Division of Narcotic Drugs (the secretariat for the Narcotics Commission) was not involved, and indeed by the summer of 1973 it still had little idea of how the American crop-substitution project was progressing, although there were suspicions that things were not moving very rapidly. What seems to have happened next is that the then opposition party in Turkey held out the removal of a ban on poppy cultivation as part of its election programme. Rather unexpectedly, it found itself in power, and committed to implement its promise. Having effectively snubbed the Americans, the party went to the United Nations for advice. With the arrival of a UN mission in the poppy-growing areas, an unappreciated factor became apparent. It was already known that the situation in Turkey was very different from that in Iran, the other Near Eastern country with a major opium poppy problem. In Iran, opium has for centuries been smoked in the villages in the areas where it is grown. In Turkey the villagers do not smoke opium, but rather the importance of the poppy crop lies primarily in the seed, as the principle source of vegetable oil for the local population and, after extraction, of oil-cake for cattle feed. The rest of the plant is 


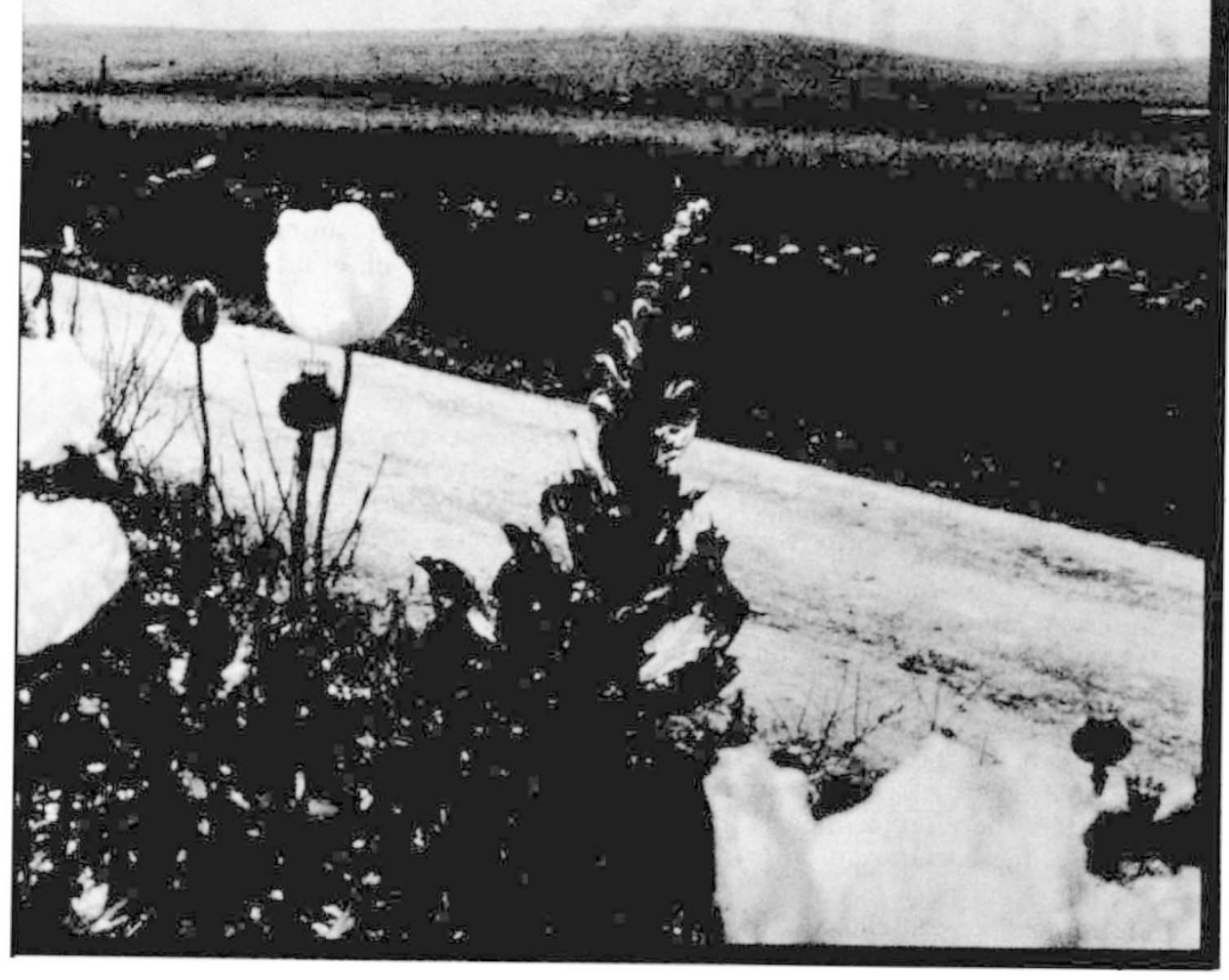

normally used for bedding for livestock. This is not to say that no opium was produced, but the poppy heads were lanced and the opium thus obtained sold, principally when a farmer needed extra funds at short notice, as for example for a wedding or a funeral.

The facts on which this UN 'discovery' were based had certainly been available to the Americans, since it was in examining their very full statistics that the mission was able to confirm what conversation with farmers and other local people had indicated: that there was little growing of the poppy solely as a source of opium. But the Americans had been so obsessed with the idea that 'Turkish opium becomes American heroin' that they had missed the real facts, and gone bullheaded for the complete and immediate prohibition of what was in fact the most important crop for perhaps 100,000 Turkish farmers. Faced with this situation, the Turkish government were to receive some $\$ 35$ million for the redevelopment of the areas affected.

The fact that opium production is not the main objective of Turkish poppy cuiture added a sound agro- and socioeconomic argument to the government's decision to rescind the ban. What will happen now is that the poppy will continue to be grown as before, until the vital two weeks during which the capsules are ripening. It is at this time that, when opium is being produced, the heads are lanced so that the opium latex can ooze out. It is a laborious business, because the grower must wait 10 to 12 hours before the hardened latex can be collected. Besides keeping several people busy for some hours, this is obviously a difficult process to conceal. It is at this period that an army of government inspectors will descend on the farmers to ensure that no lancing of capsules or illicit sale of materials takes place. Once the capsules have dried, the farmers will be able to collect the seed, both the yield and quality of which is improved when no lancing is carried out. The empty capsules and the upper parts of the stem-the "poppy straw" of commerce-will later be collected by the government for processing to extract the morphine and codeine for the pharmaceutical industry. In this way opium and hence, heroin, is bypassed completely, yet the farmers will still have the rest of the plant for livestock bedding. Moreover, by setting up their own processing plant, the Turks will not only further reduce any chance of their raw materials getting into the illicit market, but will also acquire a lucrative state monopoly. A second UN mission has in fact only recently returned to Geneva after examining the financial and technological aspects of this further project.

On the ground, plans for putting the government's scheme into action have been well advanced for some months. Farmers wishing to grow poppies must apply through defined channels, and their applications, with the area it is intended to cultivate, must be duly registered; the total area under this E crop has been put at 20,000 hectares (about 45,000 acres) spread over the $\forall$ seven provinces in which it has always been grown. The fact that these poor soils give low yields is of little immediate interest to the government; what matters is that the livelihood of the farmers is assured at least at the previous levels, particularly if the Americans can be persuaded to release the remainder of the $\$ 35$ million to help stabilise the situation in the next few years.

It is realised, of course, that this system is unlikely to be completely watertight during the first season, although the UN in Geneva are quietly confident that the Turks will attain their general objective, namely to keep Turkish-grown opium off the world market. The new system will be far simpler and probably cheaper to run than the ceaseless pursuit of illicit opium traffickers, although obviously vigilance will not be relaxed there either. But the government announcement of January 17 makes it quiet clear that the severest measures will be taken against offenders-their harvests will be destroyed, their licences will be cancelled, and no further licence will be granted in the future. Offenders will also be subject to "the relevant provisions of Turkish penal law".

A system such as this, especially if it is rigorously enforced, should provide the necessary safeguards to reassure the Americans. Recent reactions from the United States show, however, that they remain unconvinced. One Senator has been quoted by the BBC as saying that it was "obvious we will be inundated with heroin" now that the ban on opium poppy cultivation is lifted. This alarmist attitude, as reported by the $\mathrm{BBC}$, betrays a complete lack of faith in the power of the Turkish government to control the situation. It may be that, nettled by the failure of their own huge project, the Americans do not credit the facts about Turkish poppy cultivation reported by the two UN missions. But if the Turkish control system goes as planned, no opium at all will be produced and once the proposed processing plant is in operation, in two or three years time, only drugs such as morphine and codeine will come from Turkey.

Whether American pessimism or Turkish confidence will be justified is perhaps anybody's guess, and will remain so until the critical weeks of the poppy seed-or opium-harvest in May this year. 